\title{
Toward a Race Radical Vision of Bilingual Education for Kurdish Users in Turkey: A Commentary
}

\author{
Christian Faltis \\ University of California, Davis, USA
}

\begin{abstract}
This commentary presents a Race Radical Vision (RRV) for Kurdish-Turkish bilingual education in Turkey. A RRV reinforces the need to consciously include issues of racism, imperialism, identity, and local practices in the development of bilingual education teacher education programs that advocate for minoritized language use in all aspects of education. It is argued that without a RRV for bilingual education, the State will represent bilingual education to benefit of own interests, ultimately destroying bilingual education as a strong anti-racist educational practice. Turkey needs a strong RRV of Kurdish-Turkish bilingual education to ensure that racism and colonialism remain in the national educational discourse. This commentary draws on experiences of bilingual education in the United States as well as other countries to show the importance of a RRV for developing bilingual education from a local language rights perspective. It also points out some of the challenges bilingual educators and scholars face when State becomes involved in funding and shaping the anti-racist perspective in bilingual the State takes over the anti-racism practices, especially when the State is tied to neoliberalism and neoliberal ideals of individualism and colorblindness.
\end{abstract}

Keywords: Bilingual education, RRV, Kurdish, Turkey

\section{Introduction}

The implementation of models of bilingual education that advocate for and teach through a minoritized language within nation-states with large minoritized groups has typically come about as a direct result of long-term struggles against cultural genocide and racism by members of these groups (Skutnabb-Kangas \& Fernandes, 2008). As often as not, these struggles have been informed by raceradicalism (Melamed, 2011), which positions the need for materialist anti-racist forms of education, including multicultural and bilingual education, that actively and intentionally draw on and prepare teachers to understand and act against state-sanctioned monolingualism (Faltis, 2013), white and European supremacy (Said, 1978), mental colonialism, and the forced assimilation of racialized groups (Zeydanlıoğlu, 2012). The United States, Mexico, Paraguay, Southwestern China, Spain, and South Africa, among others, have a long history of implementing anti-racist forms of education to combat powerful governmental efforts to represent language and cultural policies in ways that destroy local language and cultural practices (Melamed, 2011; Ozfidan, 2014). In each of these countries, however, anti-racist programs have been difficult to sustain, especially in light of the growing state sponsored, powerful neoliberal policies that promote economic freedoms, disconnect race and racism from antiracist education, and posit that neoliberal restructuring to remove economic restrictions is the key to a post-racist world, where success is individualized through effort. In this brief commentary, I present a Race Radical Vision (RRV) for Kurdish-Turkish bilingual education in Turkey, where educational scholars and Kurdish advocates are calling for an expanded presence of multicultural and bilingual education in teacher education and for Kurdish minoritized children and youth (Aydin \& Ozfidan, 2014; Koc Damgaci \& Aydin, 2014). A RRV reinforces the need to consciously include issues of racism, imperialism, identity, and local practices in the development of bilingual education teacher education programs that advocate for minoritized language use in all aspects of education (Faltis, in preparation). I argue that without a RRV for bilingual education, the state will reduce bilingual education to forms of anti-racist language programs that benefit mainly the state's national, economic and political interests, while eventually erasing race from the national discourse and characterizing the bilingualism of minoritized language groups as desirable only to the extent that national language remains dominant. The theoretical framework for RRV is derived mainly from Jodi Melamed's work, Represent and Destroy: Rationalizing violence in the new racial capitalism (2011). 


\section{Turkey and the Suppression of Kurdish Language Use}

One country where anti-racist movements have taken an immense toll on minoritized groups is Turkey (Skutnabb-Kangas, \& Bucak, 1995). As Turkey continues its bid to become a member of the European Union, there are signs of burgeoning anti-racist educational movements to overturn severe Kurdish language restrictions and give voice to the 16 million or so Kurdish speakers, who live mainly in the eastern sections of the country, more than 2 million residing in Istanbul (Aydin \& Ozfidan, 2014). Kurdish speakers are the largest ethnic group in Turkey, approximately $18 \%$ of the total population. State suppression of the Kurdish language and cultural rights throughout the twentieth century and into the twenty-first century has been brought before the United Nations as a crime of linguistic and cultural genocide (under the definitions of genocide in articles 2(b) and 2(e) of the UN Convention on the Prevention and Punishment of the Crime of Genocide) (Skutnabb-Kangas \& Fernandes, 2008.)

Turkey, as most Westerners and some informed citizens of the United States know it, came into existence with the collapse and Westernization of the Ottoman Empire after World War I, when Mustafa Kemal Atatürk and his elite collaborators, referred to as Kremalists, declared Turkey as a modern republic in 1923 (Stanley, 2013). The Kremalists imagined a new Turkey, one that looked to Western and Eurocentric education and thought, as the single direction for the country. A significant feature of this Western orientation was the view that primitive groups - the Other - in the new republic (the Orientalists AKA the Kurds) lacked the intellectual and cultural materialism needed for becoming Westernized, and thus, needed to be brought out their backward ways. Zeydanlioglu (2008) refers to this mental colonialism and the need to civilize the Islamic, ethnic, tribal, and rural Other- other considered outside the reach of Western modernity as the "White Turkish Man's Burden". Groups within the new republic branded as Other (members of the Yellow Race) were and continue to be positioned as barriers to the social progress proposed by the White Turks, who to this day enjoy a Turkish privilege that in many ways matches White privilege in U.S society (See McIntosh, 1998; Sleeter, 2011). In 1924, The Law on the Unification of Education secularized public education and introduced mixed sex education (Stanley, 2013). By 1925, the fez and veil were outlawed as too Islamic. Soon after came new laws about the Turkish writing system- a new alphabet closer to western standards and writing from left to right. These laws were part of the Turkifacation of the new republic, a plan of forced assimilation of the Other in a national effort to create nation-state loyalty, to minimalize resistance to innovations, and to quell separatist movements (Zeydanlioglu, 2008). Essentially, these laws and policies benefitted those who were looking toward Westernization, the already privileged in society, and seriously thwarted efforts by the Other to cultivate their own language and cultural practices across generations.

The Turkifacation movement has had the greatest impact on the language and cultural practices of the Kurds in Turkey. As part of the initial Kemalist official anti-racist agenda, speaking, thinking, and acting Kurdish have been erased from the discourse of modernization in a more globalized (Eurocentric) world; if anything, being Kurdish signified obstinacy toward modernization. Early on, all languages in Turkey except Turkish were outlawed with severe punishment for public use, and all public schools had to be taught exclusively in Turkish; students who used Kurdish in school were savagely punished. Speaking Turkish was equated with being Turkish; speaking another language meant you belonged to the Other. President Atatürk, the self-proclaimed father of Turkey, argued in his new nation-building platform that "it is difficult to believe a person who claims to belong to Turkish culture and society if they don't speak Turkish" (Okutan 2004, p. 181). This nationalist unity belief has led to a series of symbolic as well as physical violence toward any ethnic group in Turkey that attempts to maintain and/or promote its local language and cultural practices.

In one of the few scholarly papers available on the Turkish language policy towards Kurdish speakers, Zeydanlioglu (2012) lays out the brutal suppression of Kurdish language use since the development post-World War I Turkey to the present. He points out that in the 1970s, thousands of Kurdish peasants were arrested, tortured, and imprisoned as separatists. The assimilationist policies of the Turkish regime reached new heights in the 1980s, eliminating any use of Kurdish in magazines, books, and newspapers; singing of Kurdish songs could only be done in Turkish. All villages with Kurdish names were changed to Turkish. Children could not be given Kurdish names that contained outlawed alphabetic letters. The new Constitution of 1982 proclaimed in Article 42 that "“"no language other than Turkish shall be taught as a mother tongue to Turkish citizens at any institutions of training or education" (Zeydanlioğl, 2012, p. 110; For the English version of the 1982 Turkish Constitution and amendments see: http://www.anayasa.gen.tr/1982constitution.htm).

\section{Official Anti-Racism as Bilingual Education}

Since the 1990s, when Turkey began its bid to become part of the newly formed European 
Union, the strict prohibition of Kurdish language in all aspects of political, educational, and social life was slowly and ever so slightly lifted in an effort by the Turkish government to appear anti-racist. This official anti-racism has led to several small, but significant changes: Kurdish language newspapers are now allowed, but the content of newspapers is constantly monitored for seditious writing. Private schools are permitted to teach Kurdish to a limited extent (as long as teachers are native Turkish speakers, and instruction falls within a certain time limit). To date, public university teacher education programs are still not allowed prepare Kurdish-Turkish bilingual teachers, although courses on general multicultural education are being taught. According to recent research, many teacher educators and school leaders are in favor of broadening educational curriculum in teacher education to include Kurdish culture and language practices and topics (Aydin \& Ozfidan, 2014; Polat, 2011). But de jure bilingual education, including literacy and content instruction in languages other than Turkish, for example, Kurdish, continues to be strictly prohibited.

The forced assimilation of Kurds into the European ideal of present-day Turkey is similar to the accommodation of children and youth of color within the anti-racist multicultural movement in the United States during 1980s and 1990s. There is much to be learned from what happened to bilingual education in the United States since its official State inception in the late 1960s. The discourse of bilingual education developed in the 1960s focused on language use as human right, on exposing and interrupting racism, and on resisting linguistic and cultural imperialism. In other words, bilingual education was informed by a race radical vision that grew out of struggles against the dominant view of education. This dominant view did everything possible to ensure that minoritized language and cultural practices were absent in the curriculum and that instruction was carried out only in the dominant language. Chicano and Native American activists and educators pushed hard for curriculum that reflected their histories, and for use of local language practices for instruction and learning (Faltis \& Hudelson, 1998)

As the State became increasingly involved in bilingual education through funding efforts and teacher education, the discourse shifted from a focus on local language and culture to the need for teachers who would provide minoritized students - increasingly positioned as having deficient language abilities - access to dominant group language practices, a kind of subtractive schooling (Valenzuela, 1999). Within this new official anti-racist model of bilingual education, local language practices were portrayed as malformed, less-than, and lacking logic (Faltis, 2013). Teachers were told about the need to inculcate emergent English learners with academic language, which they allegedly lacked. Local languages use in bilingual education was temporary, and seen as a bridge to the dominant national. By the 1990s, nationwide "bilingual education" had largely became English-only instruction for English learners, and in those states that did offer some form of transitional bilingual education, the purpose was to move children and youth into English as quickly as possible. Children and youth assigned to bilingual classrooms where physically and socially segregated from English speakers for most of the school day (Faltis \& Arias, 2007). Any issues of language rights, racism, and linguistic imperialism were essentially extirpated from the official state model of bilingual education, which claimed a post-racial realm, where language and race no longer mattered. In this official neoliberal discourse, color-blindness and individual efforts, as determined by standardized test scores from examinations given in the dominant language, are heralded as the ultimate goals for success. White privilege (McIntosh, 1998) is denied as existing. Learning a second language, marketed as bilingualism for a new global era, is linked to economic potential, and is thus considered a resource for economic development (See Selvi, 2014, for a discussion on English-Turkish bilingualism in Turkey).

To be clear, the forced assimilation of children into Western civilization in many countries has been vicious and savage, especially in Turkey. In the United States, the violence toward Mexican origin, Black, and indigenous children has also been brutal and racist (See Acuña, 2010; Dunbar-Ortiz, 2014; Ladson-Billings, 2009). In Turkey, violence and the militarization of schools in the Kurdish regions of Turkey has occurred often over a period of 60 years. Similar kinds of state repression of local languages and their representation as backwards and primitive happened in Spain with Basque, Catalán, and Galiciano users under the Franco dictatorship, and with autochthonous language users in Southwest China under Mao. These too were marred with State violence toward local language groups. In recent years, the U.S. states of Arizona, California, and Massachusetts officially banned the use of languages other than English for instruction in public schools (Arias \& Faltis, 2013). In Arizona, all courses of ethnic studies (except White ethnic studies) were banned from being taught in 2013. In each of these cases, the goal was to force minoritized children and youth to stop using their mother tongue, to relinquish their regional ethnic identity, and to forget their heritage, a kind of cultural and language hegemony strikingly akin to the social engineering policies of the Turkish state has used against Kurdish language users (Yildiz \& Duzgren, 2007). 


\section{Lessons Learned and a RRV}

Official State anti-racist approaches to addressing unrest and dissatisfaction with the treatment of local language and cultural practices other those privileged by the dominant group appears tend to be either repressive or tolerant, depending on the general acceptance of cultural difference within the State, and the potential for democratic processes to determine national policy (Faltis, 2015). Currently, there appears to be popular acceptance of the need for multicultural and bilingual education in Turkey, in order to provide voice and participation at the national level of Kurdish speakers (Aydin \& Ozfidan 2014; Koc Damagaci. \& Aydin, 2014; Polat, 2011). Accordingly, the time is right to begin re-thinking teacher education in order to prepare teachers with a deeper understanding of multicultural education as well as a set of pedagogical tools for implementing strong, local language-based bilingual education for Kurdish communities. From a RRV, Kurdish-Turkish bilingual education in universities and public schools must address issues of racism toward Kurdish communities. Public universities must find ways to actively recruit and prepare high quality Kurdish-Turkish bilingual teachers to teach in schools throughout Turkey.

In nation-states where bilingual education has become institutionalized by the government, however, efforts to maintain a race-radicalism to uncover racist and assimilationist views prevalent in the government and elite circles are challenging to sustain over time. Racism will be downplayed and cast as an individual issue rather that a systemic or grand narrative issue of the State (Melamed, 2011). For example, in a period of 30 bilingual education in the United States has essentially become a form of official antiracism that seeks to legitimize rather than oppose white supremacy and imperialism through English-only language policies. Bilingual education has been reframed as a primarily technocratic process (Grinsberg \& Saavedra, 2000) with the goal being transition into dominant rather than biliteracy development (Del Valle, 1998). In addition, even proponents of biliteracy development have resorted to deficit perspectives of emergent bilingual students--positioning them as not fully proficient in either of their two languages because of a failure to master "academic language" (Cummins, 2000). As a form of official antiracism, mainstream models of bilingual education in the United State are now sites where language and culture have become idealized objects, and the curriculum of continued human struggles against White supremacy and imperialism, particularly regarding the language practices and cultural materialism of minoritized language communities, has been largely erased.

As the discussion of bilingual education emerges and develops across Turkey, It is important to address head on issues of ideologies, policies, practice, and advocacy, asking who benefits and to what extent do preferred models of bilingual education reproduce or challenge deficit (Topbas, 2011) and race-erased views of language-minoritized students in Turkey (Zeydanlıoglu, 2012). Educators in Turkey need to be clear on the historical context that created Other-based and race erased perspectives. The work of theorizing a race-radical vision for Kurdish-Turkish bilingual education requires new conceptualizations of language, teacher education, and educational policy, and activism. Bilingual educators working within Turkey must challenges the hegemonic notion of academic language as necessary for development of Westernized thinking. And finally, for bilingual education to truly represent the language and cultural practices of minoritized groups in Turkey, teachers and community members need to be mobilized around a vital and sustainable RRV for Kurdish-Turkish bilingual education.

\section{References}

Acuña, R. (2010). Occupied America: A history of Chicanos ( $7^{\text {th }}$ Edition). New York: Pearson.

Arias, M.B. \& Faltis, C. (Eds.). (2013). Academic language and second language acquisition. Charlotte, NC: Information Age Publishing.

Aydin, H. \& Ozfidan, B. (2014). Perceptions on Mother Tongue (Kurdish) based multicultural and bilingual education in Turkey. Multicultural Education Review, 6(1), 21-48. DOI http:/dx.doi.org/10.14328/MER.2014.03.31.21

Cummins, J. (2000). Language, power, and pedagogy: Bilingual children in the crossfire. Clevedon, UK: Multilingual Matters.

Del Valle, S. (1998). Bilingual education for Puerto Ricans in New York City: From hope to compromise. Harvard Educational Review, 68, 193-217.

Derince, M.Ş. (2010). The role of first language (Kurdish) development in acquisition of a second language (Turkish) and a third language (English). (Unpublished Masters Thesis). Boğaziçi University, Istanbul.

Dunbar-Ortiz, R. (2014). An indigenous peoples' history of the United States. Boston, MA: Beacon Press. 
Faltis, C. (in preparation) Challenging race erased perspectives of language in whitestream bilingual education: Toward a Race Radical Vision. American Educational Research Association, Chicago, IL, 2015: Paper presentation.

Faltis, C. (2015). Language advocacy in teacher education and schooling. In M. Bigelow \& J. EnserKananen (Eds). The handbook of educational linguistics (pp. 65-78). New York: Routledge/Taylor \& Francis.

Faltis, C. (2013). Demystifying and questioning the power of academic language. In M. B. Arias \& C. Faltis (Eds.), Academic language and second language acquisition, (pp. 3-26). Charlotte, NC: Information Age Publishing.

Faltis, C. \& Arias, B. (2007). Coming out of the ESL ghetto: Promising practices for Latino immigrant students and English learners in hypersegregated secondary schools. Journal of Border Educational Research, 6(2), 19-35.

Faltis, C. \& Hudelson, S. (1998). Bilingual education in elementary and secondary school communities: Toward understanding and caring. Needham Heights, MA: Allyn \& Bacon.

Grinberg, J. \& Saavedra, R. (2000). The constitution of bilingual/ESL education as a disciplinary practice: Genealogical explorations. Review of Educational Research, 70, 419441.

Koc Damagaci, F. \& Aydin, H. (2014). An analysis of academics' perceptions of multicultural education: A Turkish experience. Anthropologist, 18(3), 817-833.

Ladson-Billings, G. (2009). The dream-keepers. Successful teachers of African American children. $\left(2^{\text {nd }}\right.$ edition). San Francisco: Jossey-Bass.

McIntosh, P. (1998). White privilege: Unpacking the invisible knapsack. Race, class, and gender in the United States: An integrated study, 4, 165-169.

Melamed, J. (2011). Represent and destroy: Rationalizing violence in the new racial capitalism. Minneapolis, MN: University of Minnesota Press.

Okutan, M. Ç. 2004. Tek Parti döneminde azınlık politikaları [Minority policies during the Single Party rule]. İstanbul: İstanbul Bilgi Üniversitesi Yayınları.

Ozfidan, B. (2014). The Basque bilingual education systems as a model for a Kurdish bilingual education system in Turkey. Journal of Language Teaching and Research, 5(2), 382-390. doi:10.4304/jltr.5.2.382-390

Polat, S. (2011). The attitudes of school directors to the multicultural education in Turkey. Mediterranean Journal of Social Sciences, 2(2), 385-393.

Selvi, A. F. (2014). The medium-of-instruction debate in Turkey: Oscillating between national ideas and bilingual ideals. Current Issues in Language Planning, 15(2), 133152. doi: $10.1080 / 14664208.2014 .898357$

Skutnabb-Kangas, T., \& Fernandes, D. (2008). Kurds in Turkey and in (Iraqi) Kurdistan: A comparison of Kurdish educational language policy in two sites of occupation. Genocide Studies and Prevention, 3(1), 43-73. doi: 10.1353/gsp.2011.0045

Skutnabb-Kangas, T., and Bucak, S. (1995). Killing a mother tongue: How the Kurds are deprived of linguistic human rights. In T. Skutnabb-Kangas and R. Phillipson (Eds.), Linguistic human rights: Overcoming linguistic discrimination, (pp. 347-370). Berlin: Mouton de Gruyter.

Sleeter, C. E. (2011). Becoming white: Reinterpreting a family story by putting race back into the picture. Race Ethnicity and Education, 14(4), 421-433.

Stanley, A. (2013). Transforming education in Turkey for the $21^{\text {st }}$ century: A historical guide and recommendations for leaders. Unpublished MA thesis, Northern Michigan University.

Topbas, S. (2011). Implications of bilingual development for specific language impairments in Turkey. Clinical Linguistics \& Phonetics, (11-12), 989-997.

Valenzuela, A. (1999). Subtractive schooling: U.S. - Mexican youth and the politics of caring. Albany, New York: State University of New York Press.

Yildiz, K., \& Duzgren, K. (2007). Denial of a language: Rights of Kurdish language in Turkey. In M. Erbey (Ed.), The obstacles to use Kurdish language in the public sphere (pp. 30-100). Brussels: Institute for International Assistance and Solidarity (IFIAS).

Zeydanlioglu, W. (2008). "The White Turkish Man's burden”: Orientalism, Kemalism and the Kurds in Turkey. In G. Rings \& An. Ife (Eds.), Neo-colonial mentalities in contemporary Europe? Language and discourse in the construction of identities (pp. 155-175). London: Cambridge Scholars Publishing.

Zeydanlioglu, W. (2012). Turkey's Kurdish language policy. International Journal of Sociology of Language, 217, 99-125. doi: 10.1515/ijsl-2012-0051 